\title{
Voluntary social performance disclosure and firm profitability of South African listed firms: Examining the complementary role of board independence and managerial ownership
}

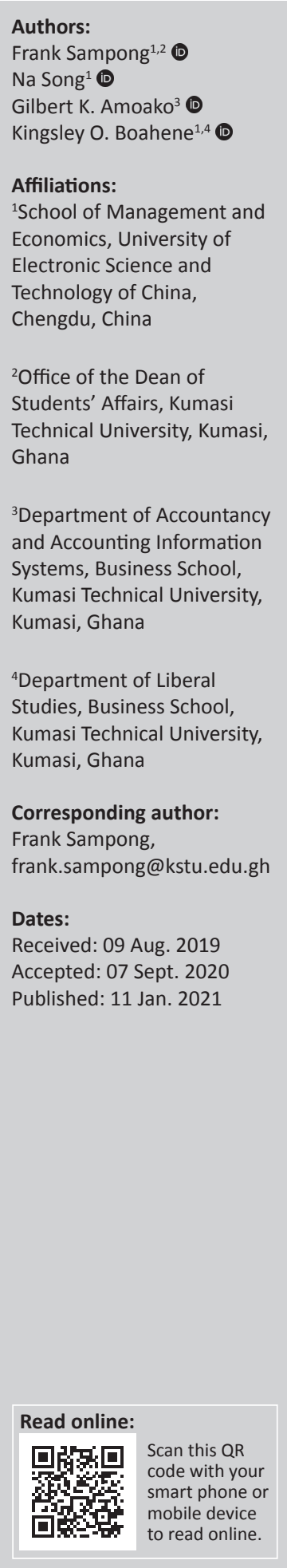

Background: There is growing literature promoting corporate governance mechanisms as important elements that could mitigate the inconclusive findings within the corporate social performance and firm profitability research. A key theoretical assumption within the extant literature that provides support for this proposition is that corporate social performance and firm profitability are organisational outcomes in the presence of good corporate governance.

Aim: Firstly, the aim is to re-investigate voluntary social performance disclosure (SPD) and long-term profitability association from the perspective of international standards, using the Global Reporting Initiative G3.1 guidelines. Secondly, to examine the joint moderating effect of board independence and managerial ownership (MO) on the voluntary SPD and profitability nexus.

Setting: The South Africa institutional setting, where recent corporate governance regimes require firms to voluntarily make corporate governance related disclosures on both shareholderand stakeholder-related information is used as the study context.

Method: Utilising manually extracted data of listed firms, over the period 2010 to 2015, the generalised least square regression and seemingly unrelated regression (with a 1-year lag as the main independent variable) are used to examine the stated hypotheses.

Results: We found a positive association between voluntary SPD and long-term profitability. We also found that the presence of non-executive directors positively moderates the association between voluntary SPD and long-term profitability. Thirdly, the proportion of MO significantly positively moderates the association between voluntary SPD and long-term profitability. Lastly, the complementary role of the presence of non-executive directors and the proportion of MO significantly positively moderates the association between voluntary SPD and longterm profitability.

Conclusion: This study finds support for scholarly theoretical arguments that organisational outcomes are largely possible in the presence of good corporate governance, which has a longterm implication for firms' shareholder wealth maximisation. This study contributes to the ongoing research examining the notion of substitutive versus complementary effects of governance mechanisms, and a growing research literature on corporate social responsibility (CSR) disclosure from the perspective of international standardisation. This study therefore makes far-reaching contributions to the corporate governance and social responsibility literature in an African context.

Keywords: corporate governance; corporate social performance; complementary/substitutive framework; global reporting initiative; emerging markets.

\section{Introduction}

Literature contends that corporate social performance (CSP) remains an important element since its components of social and environmental stakeholder concerns are likely to affect firm behaviour (Stanwick \& Stanwick 1998) and corporate decision-making (CDM). Therefore,

How to cite this article: Sampong, F., Song, N., Amoako, G.K. \& Boahene, K.O., 2021, 'Voluntary social performance disclosure and firm profitability of South African listed firms: Examining the complementary role of board independence and managerial ownership', South African Journal of Economic and Management Sciences 24(1), a3346. https://doi.org/10.4102/sajems.v24i1.3346

Copyright: @ 2021. The Authors. Licensee: AOSIS. This work is licensed under the Creative Commons Attribution License. 
previous studies have accorded the CSP and firm profitability $\left(\mathrm{FP}^{1}\right)$ nexus much attention (McGuire, Sundgren \& Schneeweis 1988). Nevertheless, to date available evidence remains inconclusive (Margolis \& Walsh 2003). Extant literature attributes the inconclusive findings to, among other things, different CSR measures and period of examination (De Klerk \& De Villiers 2012), research models adopted and endogeneity issues (Li 2016; Orlitzky, Schmidt \& Rynes 2003; Roberts \& Whited 2013). Consequently, researchers are promoting corporate governance (CG) mechanisms as important elements to mitigate (e.g. Arora \& Dharwadkar 2011; Hoje \& Harjoto 2011; Ntim \& Soobaroyen 2013) the inconclusive findings within CSP and FP literature. Extant literature provides support by arguing that CSP and FP are organisational outcomes in the presence of good CG (Aguilera et al. 2008), which has a long-term implication for firms' shareholder wealth maximisation (SWM). Thus, the SWM principle holds an inclusive, long-term financial goal reflecting investor confidence, which is measured in the face value of the firm's equity (Block \& Hirt 2002). The CG research has equally investigated the value relevance of boards' resources (e.g. Galbreath 2016; Haynes \& Hillman 2010); in particular, their individual demographic effects (e.g. board independence [BIND]) have been examined in isolation with diverse organisational outcomes, including CSR. Nevertheless, the available evidence still remains mixed. As such, our understanding as to whether or not CG mechanism interactions convey incremental value on organisational outcomes, like CSP and FP, is pretty unexplored in the African context. Again, in most cases boards have been studied as a separate decision component, outside the scope of management (Galbreath 2016). Nevertheless, theoretical evidence shows that boards have a collaborative role with management (Sundaramurthy \& Lewis 2003) in CDM. While this research line is arguably limited in the African context, there is an even more lingering research need to explore this notion on voluntary disclosures utilising international standards, due to the emergence of globalisation.

The study seeks to re-investigate the voluntary social performance disclosure (SPD) and long-term profitability (TQ) nexus from the perspective of international standards, using Global Reporting Initiative (GRI) G3.1 guidelines. Secondly, it seeks to examine the joint moderating effect of BIND and managerial ownership (MO) on the voluntary SPD and long-term FP nexus. This study is therefore premised on three viewpoints. Firstly, we argue that if boards have a collective role, with management, as a unified team to promote shareholder interests, in which MO provides directors or managers with ownership rights, then we propose that their combined effect could harmoniously promote a realignment of managerial self-interests with those of shareholders (Fama \& Jensen 1983; Jensen \& Meckling 1976). Secondly, we argue that voluntary SPD and FP are aligned to firms' SWM, which inevitably becomes a long-term goal benefiting from firms' strategic posture, since CSR actions may require a long period of time to pay off (Mahapatra 1984). Lastly, this study assumes that boards' monitoring role and managerial incentive provision are complementary in that their combined interaction is necessary for CDM (Galbreath 2016; Haynes \& Hillman 2010), to mitigate the associated financial uncertainty within organisational outcomes, like CSP and FP. For instance, it has been asserted that 'strong social performance may be primarily driven by managerial beliefs' (McGuire, Dow \& Argheyd 2003:349). This direction of research is relatively unexplored, particularly in the context of less-developed countries context. This study attempts to close this gap in research.

The South African (SA) institutional context is used for this study. Although, CG and CSR research has been extensively examined in SA, this current study further adds to our understanding and consequently makes significant contributions to the CG and CSR literature as follows: firstly, it contributes to the ongoing research debate promoting complementary versus substitutive roles of CG mechanisms (Misangyi \& Acharya 2014; Oh, Chang \& Kim 2018), particularly at the board management level (Galbreath 2016). Secondly, it sheds light on a growing literature on international standardisation of social disclosures (e.g. Garcia-Sanchez 2016; Sampong et al. 2018) by providing further evidence in an African context, in support of calls within the broader social and environmental disclosure literature. Lastly, and in line with the above two points, this study contributes, in support of calls, to refine the measures of CSR and to extend the assessment period within the CSR value relevance literature (De Klerk \& De Villiers 2012) from different institutional contexts. The outcome of this study documents a significantly positive moderating influence of the complementary effect of non-executive directors (NEDs), BIND and MO on the association between voluntary SPD and long-term profit. This follows an earlier finding of a nonsignificant positive relationship between voluntary SPD and FP. Overall, this study finds support for ongoing debates within the extant literature that the inconclusive evidence within the CSR-FP nexus could be mitigated by the interaction of CG mechanisms. The remainder of this article is organised as follows: theoretical background, prior research and hypotheses in section 2; research design, data and methodology in section 3; empirical results and additional analysis in section 4; discussion and conclusion in section 5 .

\section{Theoretical background, prior research and hypotheses}

This section utilises a multi-theoretical view to provide an understanding of previous literature, and formulates hypotheses to achieve the study's objective. Thus, consistent with extant literature, we employ the following theories: legitimacy, stakeholder, agency, resource-dependence theory (RDT), good management theory, complementary theory and 
complementary asset perspective (CAP). Thus, consistent with extant literature these theories are largely harmonising in nature rather than opposing (Reverte 2009), and provide a richer background to explore the study's aim as a result of their commonality and compatibility.

\section{Voluntary social performance disclosure and firm profitability nexus}

Two contradictory hypotheses emerge when we consider the effect of CSP on FP. The 'social impact hypothesis' - which assumes that meeting the needs and expectations of various stakeholders increases firm value - and, secondly, the 'tradeoff hypothesis', which assumes that CSP increases results in firms incurring unnecessary costs which so lead to a reduction in value (Donaldson \& Preston, 1995). This puts socially proactive and responsible firms at a disadvantage compared with less socially active ones (Peng \& Yang 2014; Preston \& O'Bannon 1997). The CSP and FP nexus has extensively garnered prior research, with some widely cited groundbreaking studies (e.g. McGuire et al. 1988; Orlitzky et al. 2003). Nevertheless, to date the available empirical findings remain largely mixed and inconsistent (McGuire et al. 1988). Advocates of a positive CSP-FP nexus hold a view that not only may voluntary CSP be considered a business objective in itself, but it also serves as a means to an end with regard to FP. On the other hand, those who found a negative relationship suggest that firms' investment in voluntary CSP diverts funds that could have been channelled into other productive investments (Peng \& Yang 2014; Preston \& O'Bannon 1997). As argued in extant literature, the mixed findings within the CSP-FP nexus have also been attributed to: methods, model specification and endogeneity issues (e.g. Li 2016; Orlitzky et al. 2003; Roberts \& Whited 2013) and the social disclosure patterns across different industries and the institutional micro- and macro-settings (e.g. GarciaSanchez et al. 2016, Tshipa et al. 2018), due to associated costs and benefits with diverse industry features. The SA context makes an interesting case to examine voluntary social disclosures, specifically due to its long history of racial segregation, termed apartheid, which resulted in many social disadvantages to the majority of the SA population (Southall 2004). Consequently, Sampong, Boahene and Kweitsu (2018) contend that the practice of social disclosures has mainly been influenced by 'apartheid'. Nevertheless, the unique CG codes have voluntarily promoted social disclosure in line with international standards. Specifically, the King III CG report recommends that all entities in SA should promote a voluntary disclosure regime based on the third-generation reporting standard (GRI, G3) (IoDSA, 2009). Supporters of social and global reporting standards have equally long contended that social disclosures offer reporting organisations a wide spectrum of intangible benefits, which extends to the firm's balance sheet (Adams 2004). Although evidence of the CSP-FP nexus has generally been mixed, theoretical understanding generally supports a positive direction (Orlitzky et al. 2003). In the SA context, a study that examined inclusion on the Johannesburg Stock Exchange (JSE) socially responsible index and FP found no association using logistic regression (Du Toit \& Lekoloane 2018). De Klerk and De Villiers (2012), using a modified Ohlson model, found that corporate responsibility reporting is significantly positively related to market value. Horn, De Klerk and De Villiers (2018) using survey data by KPMG International on CSR contend that social disclosure has a positive but weak effect on future profits. The advent of socially responsible behaviour, linked to international standardisation, through sustainability reports, ultimately seeks to ensure the long-term sustainability and survival of organisations, while maximising shareholder value and FP. Thus, socially responsible behaviour can be a competitive advantage to ensure firms' long-term profitability. Socially responsible behaviour (and its related disclosure practices) is a management practice that ensures an organisation maximises the positive impact of its operations on society in a manner that meets and exceeds the legal, ethical and public expectations. Therefore, social responsibility creates a positive long-term value for shareholders even in conditions of uncertainty (McWilliams \& Siegel 2000). For instance, Waddock and Graves (1997) found that an increase in CSR could lead to enhanced long-term profitability. Supporters of international disclosure standards on social responsibility have long contended that disclosure offers reporting companies a positive impact on FP. Studies specifically covering transparency and disclosure have indicated a positive market reactions, which could lead to a corresponding impact on firm value (Adams 2004). Therefore, based on the available empirical and theoretical evidence within the extant literature that socially responsible behaviour leads to a positive impact on firm profits (Orlitzky et al. 2003), we hypothesised that:

H1: Ceteris paribus, voluntary SPD is positively associated with long-term profitability.

\section{Moderating role of non-executive directors on voluntary social performance disclosure and firm profitability nexus}

The call for appropriate representation of NEDs on boards (i.e. board independence) has largely been based on agency theory (AT) and RDT. Agency theory asserts that boards have a monitoring and controlling role over managers due to their opportunistic behaviour (Fama \& Jensen 1983; Jensen \& Meckling 1976). For instance, outside directors have more opportunity for control and face complexities stemming from their responsibilities as directors (Mangel \& Singh 1993). Resource-dependence theory notes that the existence of boards serves as an essential link between firms and their critical resources needed to maximise value (Pfeffer 1973:350). For example, NEDs offer essential resources, by promoting board independence (Haniffa \& Cooke 2002:319) towards voluntary social disclosures. Thus, RDT proposes that the unique composition of boards, including expertise, is a firm's resource (Hillman \& Dalziel 2003) that could affect its value (Pfeffer \& Salancik 1978). In particular, RDT views the board composition as firms' value-added resources. For instance, larger boards with professionals increase the firm's expertise and resources (Pfeffer \& Salancik 2003). Boards perform a 
critical supervisory and monitoring role, which is central to ensure that managers act in the best interest of shareholders (Fama \& Jensen 1983; Jensen \& Meckling 1976). In spite of the trade-off that may exist between social disclosure and FP, prior research argues that managers may undertake social responsibility activities for their own benefit, such as public fame, at the expense of their firms' SWM goal. For instance, managers may seek to divert stakeholders' attention from a poorly performing firm by improving its CSR activities (Preston \& O'Bannon 1997). On the other hand, managers may reduce CSR overheads in order to boost short-term gains to enhance their personal rewards. These two views show that at the board management level, social disclosure could be used as a signal towards managerial benefits, which could have an adverse effect on firm value whenever managers act unfavourably towards stakeholder interest (Baird, Geylani \& Roberts 2012). Therefore, towards re-aligning the principal agency conflicts is the promotion of good CG. Prior researchers have argued that CSR disclosure may have a limiting effect on firm value (Horn et al. 2018; Sampong et al. 2018) and that because of this possibility, the associated benefits of CSR disclosure for firms are largely dependent on good CG (Aguilera et al. 2008). Therefore, the existence of good CG, in particular BIND, could avert corporate irresponsibility. This could lead to an enhanced positive effect of voluntary SPD on FP. The reverse is a situation that can aggravate conflicts among various stakeholders (Hoje \& Harjoto 2011) and could result in poor CDM benefits from ineffective CG. In the SA context, the promotion of BIND has been advocated by CG codes. For instance, formal CG regimes have sought to largely promote BIND. The 2009 CG code of SA, King III (IoDSA, 2009), requires boards to have the majority of NEDs to facilitate increased monitoring, towards shareholder and stakeholder CG-related disclosures (Gyapong \& Afrifa 2019). The extant literature found a positive impact of the presence of NEDs on social disclosure and FP (Ntim \& Soobaroyen 2013). From the available empirical findings, one can establish that the proportion of NEDs should potentially have a positive moderating impact on the association between social disclosure and FP. Arguably, the presence of NEDs on boards provides positive growth, with potentially positive implications for FP and voluntary disclosure (Ntim \& Soobaroyen 2013). Hence, we hypothesised that:

H2: Ceteris paribus, the presence of NEDs on boards will enhance the positive voluntary social performance disclosure and long-term profitability nexus.

\section{Moderating role of managerial ownership on voluntary social performance disclosure and firm profitability nexus}

Agency theory suggests that $\mathrm{MO}$ has the potential to align the divergent interests of managers with those of shareholders. Hence, extant literature empirical evidence shows that MO impacts on organisational outcomes. Johnson and Greening (1999), for instance, found a positive relationship between top management's equity and CSP. The good management theory asserts that there exists a positive association between CSP and firm value (Graves \& Waddock 1994); if so, then MO could promote a more active voluntary social disclosure among managers. Hence, the conclusion could hold that MO might enhance initiatives to engage more in voluntary social disclosure in support of FP. This is because managers have power to allocate resources among the wider stakeholder group; hence the provision of managerial incentives (e.g. stocks and bonds) could be an effective way to mitigate associated agency conflicts, and to help align the conflicting interest of agents to those of the owners (Fama \& Jensen 1983; Jensen \& Meckling 1976). More so, where managers own a significant part of the firm's equity, decisions regarding promoting CSR could be better achieved (McConnell \& Servaes 1990). However, it has arguably been noted that the different institutional contexts largely exhibited, due to wider differences in development (e.g. Garcia-Sanchez et al. 2016; Sampong et al. 2018), may affect voluntary disclosure differently in developing economies. Campbell (2007) argues that developed economies (like the United States and United Kingdom) may impose greater institutional pressure (Campbell 2007) on managers to undertake more socially related disclosures. However, in developing countries, like SA - where investor protection is relatively low as a result of a weaker external regulatory environment (LaPorta et al. 2000) - managers may not be subjected to mandatory forms of pressures. Unlike the United States and United Kingdom, ownership within SA companies is typically characterised by high block and institutional ownership, mainly in the form of complex cross-ownerships and tall pyramids. Nevertheless, SA CG codes encourage directors and managers to own shares in companies in order to improve interest alignment, including specifying performance-related elements of director pay (Barr, Gerson \& Kanto 1995). For instance, evidence within extant literature supports a positive relationship between top management equity ownership and CSP (Johnson \& Greening 1999). By implication, MO should enhance initiatives to engage more in voluntary social disclosures in support of long-term profits. This is because managers have power to allocate resources among wider stakeholder groups, and so, whenever managers own significant part of firms' equities, decisions regarding promoting CSR and its related disclosure could be achieved much easier, which should lead to increased profitability. From the above, we hypothesised that:

H3: Ceteris paribus, the percentage of managerial shareholding will enhance the positive voluntary social performance disclosure and long-term profitability nexus.

\section{Complementary role of non-executive directors and managerial ownership on voluntary social performance disclosure and firm profitability nexus}

The complementary theory (Aguilera et al. 2008:483) and CAP (Dierickx \& Cool 1989; Galbreath 2016) both highlight the collective nature of boards and management in CDM. Complementary theory presents a more integrative view of CG that considers how governance elements interact and 
potentially complement each other (Aguilera et al. 2008) to impact on CDM, including voluntary disclosure. Inherently, extant literature notes that because there may be great difficulty and uncertainty involved in observing executive behaviours, as well as in measuring performance outcomes in corporations, managerial incentives and boards' monitoring role may necessarily function as complements, as the two must be present for effective governance (Aguilera et al. 2008; Galbreath 2016; Milgrom \& Roberts 1992). In a similar vein, and as implied by the RDT (Pfeffer \& Salancik 1978, 2003), CG structures are critical firm resources that are used to achieve organisational goals. Hence for effective $\mathrm{CDM}$, the firm's resources must be uniquely combined to achieve success (Misangyi \& Acharya 2014). This supports the CAP. The CAP suggests, for instance, that there are 'strong relations of complementarity and co-specialization among individual resources, so that it is not really the individual resources but rather the way resources are clustered and how they interact' (Foss 1998:143), which is important for competitive advantage. Thus, CAP holds that the effective applicability of the firm's resources means that there exists a bilateral dependence among the resources (Galbreath 2016). As such, it has been argued that anything that is a strength or weakness to the firm can be considered as a resource (Wernerfelt 1984). For instance, Aguilera et al. (2008) suggested that 'performance incentives for executives are more effective when complemented with a high level of board independence and an effective market for corporate control' (as cited in Misangyi \& Acharya 2014). Evidence on the effect of board independence on voluntary CSR and firm value supports a positive effect. Similarly, the impact of MO has been found to be positive. Arguably, these mechanisms are firm resources that aid the SWM goal. As such, it is believed that all individual units are contributors towards the firm's SWM and its overall survival. Hence, we argue that the complementary interaction of the firm's available resources is particularly necessary towards the achievement of optimal organisational gains. For instance, Aguilera et al. (2008) suggested that 'performance incentives for executives are more effective when complemented with a high level of board independence and an effective market for corporate control' (as cited in Misangyi \& Acharya 2014). From the aforementioned theoretical and empirical evidence, we could conclude that CG mechanisms, from the perspective of utilising them as complements, should have a high marginal impact on the different organisational activities, compared with their individual effects. Thus, the board management monitoring roles and performance incentives must be present for effective governance and CDM (Galbreath 2016; Milgrom \& Roberts 1992). Therefore, from the above, we could argue that the firm's monitoring functions and incentive alignment are necessary to mitigate the agency conflict. Hence, the following hypothesis is formulated:

H4: Ceteris paribus, the complementary effect of the proportion of NEDs on board and percentage of managerial shareholding will incrementally enhance the positive voluntary social performance disclosure and long-term profitability nexus.

\section{Research data, design and methodology \\ Sample selection and data}

This study utilised an unbalanced data set of 126 listed JSE firms during the 2010 to 2015 period. Data were obtained from the African Market database. We excluded firms with more than 2 years missing data and all financial institutions, which produced total firm-year observations of 747. Our data set indicates both cross-sectional and time series components. Hence, given the nature of the data and to allow for time series and cross-sectional data observations, this study employs a panel regression technique. This is consistent with extant literature. South Africa is chosen as our study context because of its many unique features that seek to promote good CG and social disclosure. For instance, CG in the SA context has arguably been noted as well developed, which compares well with most developed and middle-income economies. Again, although the SA CG regimes stress the need to comply with affirmative actions, it equally endorses a voluntary disclosure regime based on international reporting standardisation (Sampong et al. 2018).

\section{Variables description and measures \\ Dependent variable}

Tobin's Q (TQ) is the dependent variable, which is a measure of long-term FP. This measure of FP has extensive coverage and usage in extant literature (e.g. Sampong et al. 2018; Waddock \& Graves 1997). Tobin's Q reflects the market's expectations of future earnings, which is a measure of expected future prospects of the firm (Waddock \& Graves 1997). This measure has a long-term implication for firms' SWM objective. Other forms of FP, like return on assets (ROA) and return on equity (ROE), are short-term profits which aid the day-to-day running of the organisation, hence we control for their effects in this study.

\section{Independent variable}

Social performance disclosure is the main independent variable, which is an index constructed through the manual extraction of socially related disclosure information in annual and CSR reports of sample companies. The information collected was then analysed in line with the 45 indicators on social performance of the GRI G3.1 guidelines ${ }^{2}$, to ascertain the extent of voluntary SPD. The use of the GRI G3.1 guidelines was motivated by recommendations of the 2009 SA CG code of SA, which encourages all entities in SA to follow and report, based on the third-generation GRI guidelines to promote international standardisation in the sub-Saharan African region, King III (IoDSA, 2009). The GRI guidelines feature a modular, interrelated structure, and represent the global best practice for reporting on a range of social issues, and have generally been acknowledged as a 2.Available at https://www.globalreporting.org/resourcelibrary/G3.1-Guidelines-InclTechnical-Protocol.pdf 
TABLE 1: Variable description.

\begin{tabular}{|c|c|c|}
\hline$\underline{\text { Variable }}$ & Code & Description \\
\hline \multicolumn{3}{|l|}{ Dependent variable } \\
\hline Tobin's Q & TQ & Total market value of the firm to total asset value \\
\hline \multicolumn{3}{|l|}{ Independent variable } \\
\hline Social performance disclosure & SPD & $\begin{array}{l}\text { A disclosure index manually constructed based on the } 45 \text { social performance indicators of the GRI G3.1 disclosure } \\
\text { guidelines }\end{array}$ \\
\hline \multicolumn{3}{|l|}{ Moderating variables } \\
\hline Board independence & BIND & Proportion of non-executive directors on boards \\
\hline Managerial ownership & MO & Percentage of manager or director shareholdings \\
\hline \multicolumn{3}{|l|}{ Control variables } \\
\hline Firm size & FSIZE & Natural logarithm of year-end of total assets \\
\hline Firm age & FAGE & Natural logarithm of the number of years from a firm's founding year to 2010 , start year for the study period \\
\hline Capital expenditure & CAPX & Percentage of total capital expenditure to total assets \\
\hline Leadership structure & CEO-CHAIR & A dummy variable equal to ' 1 ' if the positions of CEO and chairman are separately held, otherwise 0 \\
\hline Big four audit firm & B4AUD & A dummy variable equal to ' 1 ' if a firm is audited by a Big Four audit firm, otherwise ' 0 ' \\
\hline Corporate social responsibility committee & CSRCOM & A dummy variable equals to ' 1 ' if a firm has a corporate social responsibility committee, otherwise 0 \\
\hline Leverage & LEV & Ratio between the volume of a firm's short-term and long-term debt to its total assets \\
\hline Industry dummies & - & $\begin{array}{l}\text { Coded } 1 \text { to } 7 \text { for basic materials, consumer goods, consumer services, oil and gas, telecommunications, healthcare } \\
\text { and technology industries }\end{array}$ \\
\hline Year-dummies & - & Coded 1 to 6 for each of the 6 years from 2010 to 2015 inclusive \\
\hline
\end{tabular}

leader in international standards (Mahoney et al. 2013) and regarded a primary tool for disclosure, due to their wide applicability. Prior research suggests that content analysis provides valid results for social disclosure research, allowing the researcher to appraise the extent of various items' disclosure (e.g. Krippendorff 2004; Guthrie et. al. 2004). A key issue in content analysis research is the unit of measure, which is an identifiable component of communication through which variables are measured. The application of content analysis includes word count, sentences or sections, or reading the whole text, the use of advanced software packages to extract information from reports and a dichotomous variable technique (e.g. Krippendorff 2004). We used the latter as it has extensive usage in disclosure research, and has proven to be reliable. Hence, this study follows prior disclosure research that used a disclosure index and the binary coding technique. The issue of reliability and approval of the quality of content analysis adopted also becomes very important. Therefore, to increase reliability and minimise bias (Potter \& Levine-Donnerstein 1999), every effort was made by the authors to remain objective in the scoring and coding process. As such, all socially related disclosure information in annual and CSR reports were analysed and coded twice and, subsequently, scores compared by the authors to ensure that all relevant information was captured and interpreted correctly. A disclosure index $\mathrm{SPD}_{i t}$ was calculated by:

$\operatorname{SPD}_{i t}=\frac{\sum_{i=0}^{n} X_{i t}}{m_{i t}}$

In Equation 1, $\mathrm{m}_{i t}$ is maximum expected score for each category, $j$ is the company, $i$ is the items and $X_{i t}$ assumes a value of 1 if a firm disclosed an item, otherwise 0 , so that, $\mathrm{SPD}_{i t}$ lies between 0 and 45 . However, where a provision does not apply to an industry, we neither score nor penalise.

\section{Moderating variables}

The notion of BIND is largely promoted in SA CG codes, towards the effective monitoring of boards for both shareholder- and stakeholder-related disclosures. For instance, King III specifically sought to ensure SA BIND towards effective board monitoring by, for instance, advocating for a unitary board structure with majority NEDs $^{3}$ (Gyapong \& Afrifa 2019). Managerial ownership is an essential CG mechanism that can reduce agency problems by aligning the interests of shareholders and managers. Extant literature suggests that as the proportion of equity owned by managers increases, their interests will align increasingly more with those of shareholders, denying them the luxury to indulge in opportunistic behaviours (Fama \& Jensen 1983; Jensen \& Meckling 1976). Following extant literature, MO is measured as the percentage of managerial shareholding. ${ }^{4}$

\section{Control variables}

This study employs several control variables to mitigate potentially omitted variable bias. Thus, we include these variables in all our regression models to account for factors other than the theoretical constructs of interest that could explain variations in the variables of interests. We rely on extant literature (e.g. Arora \& Dharwadkar 2011; Sampong et al. 2018; Tshipa et al. 2018; Waddock \& Graves 1997) to select our control variables. These are firm size, firm age, capital expenditure, leadership structure, operating profit, presence of a CSR committee and leverage. The extant literature finds mixed evidence on the effect of these control variables on CSR and FP. We predict that the effects of the control variables on the dependent and independent variables will be consistent with the mixed findings within the existing literature. Finally, we control for variations across time and industry, by including year and industry dummies (see Table 1 for all variable description).

3.Non-executive directors are those highlighted as outside directors or NEDs in the companies' annual reports.

4.Managerial share ownership are those indicated under shareholder types or analysis for directors and managers in the annual reports. 


\section{Results}

\section{Descriptive statistics and correlation matrix}

Table 2 presents a summary of descriptive statistics (i.e. mean and standard deviation) and the inter-construct Spearman correlation matrix for the study variables (excluding industry and year-dummies). It shows a mean of 1.974 for $T Q$, suggesting that, on average, most sample companies exhibited a positive long-term FP over the review period. Also, SPD has a mean of 0.690 , suggesting that, on average, the extent of voluntary SPD among sample companies, on the basis of the GRI-G3.1 guidelines, was approximately $69 \%$, which is reasonably high. Also, the mean for NEDs (BIND) is 0.272 , suggesting that, on average, there are about $27 \%$ NEDs on the sample companies' boards over the study period. Additionally, MO has a mean of 5.912, suggesting that, on average and across the sample firm-years, managers' share-ownership was approximately $6 \%$. Table 2 also presents the correlation among the variables. The Spearman correlation matrix was utilised as a measure of the strength and direction of association. Table 2 reveals the following associations: SPD is significantly negatively related to TQ. Non-executive directors is positively related to TQ and SPD, while MO is negatively related to TQ and SPD.

\section{Panel regression method}

Our final data set produced unbalanced data as there were some missing years; hence, to take advantage of the variations in the variables of interest over time, an unbalanced regression panel is employed. However, before deciding on an appropriate estimation technique, and consistent with extant literature (e.g. Haniffa \& Hudaib 2006), preliminary tests are performed. We assess multicollinearity using the correlation matrix (Table 1), which shows multicollinearity is non-existent. We also use the variance inflation factors (VIFs), which show a range of 1.02 to 0.98 (with tolerance levels ranging from 0.83 to 0.98 ). The range of VIFs falls outside the conventional threshold of 10 (Kennedy 1998). Lastly, we test for internal consistency of voluntary SPD index using the Cronbach's alpha test. The outcome shows an overall coefficient alpha of 0.724 , which is indicative of internal reliability (Potter \& Levine-Donnerstein 1999). The unbalanced nature of our data set indicates that the use of an ordinary least square (OLS) regression method may not be appropriate, as it assigns equal weight to each observation and does not use information relating to unequal variability within the data. The generalised least square (GLS) regression, however, can produce more accurate estimators in the presence of outliers and unequal data variability, because it accounts for such information. It is equally able to capture firm-specific effects and also able to control for individual heterogeneity within the data set (e.g. Tshipa et al. 2018).

\section{Econometric model estimation}

The econometric model is employed to test the stated hypotheses:

$$
\begin{aligned}
\mathrm{TQ}_{i t}= & b_{0}+b_{1} S P D I_{i t}+b_{2} S P D I_{i t} * N E D s_{i t}+b_{3} S P D I_{i t} * M O_{i t}+b_{4} S P D I_{i t} \\
& * N E D s_{i t} * M O_{i t}+\sum_{i=1}^{7} b_{5} \text { CONTROLS } S_{i t}+\varepsilon_{i t}
\end{aligned}
$$

In Equation 2, $b_{0}$ is the intercept, $\varepsilon$ is the error term and CONTROLS is the control variables. All variables are as defined in Table 1.

\section{Hypotheses testing and findings}

In Table 3 the model fit information shows that all the regression models are statistically significant which indicates a better model fit, and reflects the model's adequacy. Wald's chisquared test is used to test the level of representation, which is also dependent on the significance levels, allowing for the acceptance or rejection of the models. Hence, all the models show significant adequacy. In Table 3, all models' Wald's chisquared values are statistically significant (at 0.0001) for a 95\% confidence level. This suggests that common method bias may not be a problem in our analysis (e.g. Podsakoff et al. 2003). In total, three models were estimated to test the stated hypotheses. However, consistent with prior studies (e.g. Galbreath 2016; Oh, Chang \& Cheng 2018) we first test the

\begin{tabular}{|c|c|c|c|c|c|c|c|c|c|c|c|c|c|c|c|}
\hline Variable & $N$ & Mean & $\begin{array}{l}\text { Standard } \\
\text { deviation }\end{array}$ & TQ & SPD & BIND & MO & FSIZE & FAGE & CAPX & CEO-CHAIR & B4AUD & ROA & CRSCOM & LEV \\
\hline TQ & 747 & 1.974 & 2.673 & 1.000 & - & - & - & - & - & - & - & - & - & - & - \\
\hline SPD & 747 & 0.690 & 0.188 & $-0.136 *$ & 1.000 & - & - & - & - & - & - & - & - & - & - \\
\hline BIND & 747 & 0.272 & 0.225 & 0.071 & 0.056 & 1.000 & - & - & - & - & - & - & - & - & - \\
\hline MO & 745 & 5.912 & 13.533 & -0.024 & $-0.106 *$ & 0.015 & 1.000 & - & - & - & - & - & - & - & - \\
\hline FSIZE & 747 & 22.082 & 2.518 & -0.072 & $0.107^{*}$ & $-0.091^{*}$ & $-0.330 *$ & 1.000 & - & - & - & - & - & - & - \\
\hline FAGE & 745 & 3.224 & 0.951 & 0.026 & -0.007 & $-0.142^{*}$ & $-0.110 *$ & $0.207^{*}$ & 1.000 & - & - & - & - & - & - \\
\hline CAPX & 747 & 5.313 & 8.658 & 0.061 & -0.019 & -0.020 & $0.094^{*}$ & -0.027 & $0.122 *$ & 1.000 & - & - & - & - & - \\
\hline CEO-CHAIR & 747 & 0.958 & 0.200 & $0.194^{*}$ & $-0.080 *$ & 0.008 & -0.019 & $0.082^{*}$ & $0.097^{*}$ & -0.058 & 1.000 & - & - & - & - \\
\hline B4AUD & 747 & 0.762 & 0.426 & 0.001 & $0.113^{*}$ & -0.058 & $-0.156^{*}$ & $0.352^{*}$ & $0.277^{*}$ & -0.052 & $0.079^{*}$ & 1.000 & - & - & - \\
\hline ROA & 747 & 0.075 & 0.135 & $0.234^{*}$ & $-0.173^{*}$ & -0.072 & -0.005 & $0.122^{*}$ & $0.181^{*}$ & 0.004 & $0.076^{*}$ & $0.159 *$ & 1.000 & - & - \\
\hline CRSCOM & 747 & 0.952 & 0.214 & -0.005 & 0.003 & $-0.076^{*}$ & $0.223^{*}$ & $0.173^{*}$ & $0.235^{*}$ & $0.107^{*}$ & -0.050 & $0.239 *$ & $0.181 *$ & 1.000 & - \\
\hline LEV & 747 & 0.522 & 2.098 & -0.061 & -0.071 & $-0.112 *$ & 0.040 & $0.179 *$ & $-0.092 *$ & 0.003 & 0.018 & $0.109 *$ & $-0.103 *$ & -0.066 & 1.000 \\
\hline
\end{tabular}

TABLE 2: Descriptive statistics and correlation matrix.

Note: This table presents the descriptive statistics and correlation matrix for the study variables. * indicates significance at $5 \%$. Variables are as defined in Table 1.

TQ, Tobin's Q; SPD, Social performance disclosure; BIND, Board independence; MO, Managerial ownership; FSIZE, Firm size; FAGE, Firm age; CAPX, Capital expenditure; CEO-CHAIR, Leadership structure; B4AUD, Big four audit firm; ROA, Operating profit; CRSCOM, Corporate social responsibility committee; LEV, Leverage. 
TABLE 3: Generalised least square regression results examining the moderating role of board independence and managerial ownership on the voluntary social performance disclosure and firm profitability nexus.

\begin{tabular}{|c|c|c|c|c|c|c|c|c|c|c|}
\hline \multirow[t]{3}{*}{ Variable } & \multicolumn{4}{|c|}{ Model 1} & \multirow{2}{*}{\multicolumn{2}{|c|}{$\begin{array}{c}\text { Model } 2 \\
\text { TQ }\end{array}$}} & \multirow{2}{*}{\multicolumn{2}{|c|}{$\frac{\text { Model } 3}{\text { TQ }}$}} & \multirow{2}{*}{\multicolumn{2}{|c|}{$\frac{\text { Model } 4}{\text { TQ }}$}} \\
\hline & \multicolumn{2}{|c|}{ TQ } & \multicolumn{2}{|c|}{ SPD } & & & & & & \\
\hline & $\beta$ & z-stats & $\beta$ & z-stats & $\beta$ & z-stats & $\beta$ & z-stats & $\beta$ & z-stats \\
\hline Constant & $7.296 * * *$ & 7.39 & $6.018 * * *$ & -5.42 & $6.934 * * *$ & 6.49 & $6.769 * * *$ & 6.35 & $6.465 * * *$ & 6.07 \\
\hline \multicolumn{11}{|l|}{ Control variables } \\
\hline FSIZE & $-0.332 * * *$ & -8.48 & 0.002 & 1.37 & $-0.332 * * *$ & -8.52 & $-0.337 * * *$ & -8.71 & $-0.335 * * *$ & -8.69 \\
\hline FAGE & -0.035 & -0.34 & 0.000 & 0.08 & -0.357 & -0.34 & -0.064 & -0.61 & -0.096 & -0.91 \\
\hline CAPX & $0.044 * * *$ & 4.15 & $0.011 * *$ & 2.37 & $0.043 * * *$ & 4.06 & $0.040 * * *$ & 3.67 & $0.040 * * *$ & 3.86 \\
\hline CEO-CHAIR & $1.539 * * *$ & 3.34 & $0.038^{*}$ & 1.81 & $1.513 * * *$ & 3.28 & $1.630 * * *$ & 3.57 & $1.577 * * *$ & 3.47 \\
\hline ROA & $1.432 * *$ & 1.97 & $0.081 * * *$ & 3.75 & $1.425 * *$ & 1.96 & $1.498 * *$ & 2.08 & $1.567 * *$ & 2.18 \\
\hline CRSCOM & -0.229 & -0.49 & 0.011 & 0.33 & -0.284 & -0.60 & -0.237 & -0.51 & -0.165 & -0.40 \\
\hline LEV & -0.011 & -0.26 & -0.002 & -1.04 & -0.010 & -0.22 & -0.012 & -0.28 & -0.016 & -0.37 \\
\hline \multicolumn{11}{|l|}{ Independent variable } \\
\hline SPD & - & - & - & - & 0.059 & 0.85 & 0.076 & 0.093 & $0.132 *$ & 1.85 \\
\hline \multicolumn{11}{|l|}{ Moderating variables } \\
\hline SPD* NEDs & - & - & - & - & - & - & 0.086 & 1.23 & $0.214^{* *}$ & 2.20 \\
\hline SPD*MO & - & - & - & - & - & - & $0.346 * * *$ & 3.45 & $0.672 * * *$ & 4.45 \\
\hline SPD* NEDs *MO & - & - & - & - & - & - & - & - & $0.466 * *$ & 2.87 \\
\hline Industry effects $\dagger$ & - & - & - & - & - & - & - & - & - & - \\
\hline Years effects $\uparrow$ & - & - & - & - & - & - & - & - & - & - \\
\hline Wald's chi-squared & $149.22 * * * *$ & - & $856.67 * * * *$ & - & $150.08 * * * *$ & - & $164.700 * * * *$ & - & $174.790 * * * *$ & - \\
\hline$\Delta$ Wald's chi-squared & - & - & - & - & 0.86 & - & 14.62 & - & 10.09 & - \\
\hline Log likelihood & -1721.65 & - & 573.941 & - & -1721.29 & - & -1705.656 & - & -1701.553 & - \\
\hline Observations & 745 & - & 745 & - & 745 & - & 743 & - & 743 & - \\
\hline
\end{tabular}

$\dagger$, Included.

TQ, Tobin's Q; SPD, Social performance disclosure; NED, non-executive directors; MO, Managerial ownership; FSIZE, Firm size; FAGE, Firm age; CAPX, Capital expenditure; CEO-CHAIR, Leadership structure; ROA, Operating profit; CRSCOM, Corporate social responsibility committee; LEV, Leverage.

$* * * *, p \leq 0.001 ; * * *, p \leq 0.01 ; * *, p \leq 0.05 ; *, p \leq 0.10$ significance level, two-coefficient test. All variables are as defined in Table 1.

control variables effects separately on TQ and SPD, in baseline Model 1. Our approach may slightly differ from previous studies, because this study examines the relationship between voluntary SPD and FP. The results are largely consistent with mixed findings within the extant literature: showing positive, negative and non-significant effects (see Table 3, Model 1 and Model 2).

\section{Voluntary social performance disclosure and firm profitability nexus}

Table 3, Model 2 tests the direct relationship between voluntary SPD and TQ. We modelled SPD, including all the control variables, on TQ. H1 suggests a positive voluntary SPD and long-term FP nexus. The outcome, Table 3, Model 2 , supports our prediction of a positive relationship $(\beta=0.059)$. Hence, our finding is consistent with the general positive theoretical notion in extant literature. Earlier researchers that found a positive relationship are De Klerk and De Villiers (2012), as well as Spicer (1978). Hence, our finding for H1 supports the 'social impact hypothesis'.

\section{Moderation test of board independence and managerial ownership}

The test for moderation follows recommendation by Dawson (2014) that an important decision to make before starting the moderation process is whether to use the independent and moderator variables in their raw form or to standardise them. We employed the latter. $\mathrm{H} 2$ and $\mathrm{H} 3$ suggest that the individual moderating effects of NEDs (BIND) and MO will enhance the direct positive voluntary SPD and FP nexus. In Model 3, both the two-way interaction terms (i.e. SPD*NEDs and $\mathrm{SPD}^{* \mathrm{MO})}$ are added to the analysis, because multicollinearity was non-existent (Schroeder 1990). Firstly, Table 3, Model 3 supports our prediction for H2. The moderating effect of NEDs (BIND) on the voluntary SPD and FP nexus is positive $(\beta=0.086)$ showing an increase of $\beta=0.027$, compared with Model 2; however the effect was non-significant. Based on this we argue in favour of a partial moderation effect of NEDs (BIND). Secondly, the moderating effect of MO, Table 3, Model 3, is significantly positive $(\beta=0.346 ; p \leq 0.01)$ on the association between voluntary SPD and FP. Hence, H3 is also supported. Finally, H4 examines the existence of a complementary role of NEDs and MO. Model 4 adds the three-way interaction term (i.e. SPD*NEDs*MO) to the analysis. The results in Table 3, Model 4 show that the combined effect of NEDs (BIND) and $\mathrm{MO}$ was significantly positive $(\beta=0.466 ; p \leq 0.05)$, moderating the direct positive voluntary SPD and TQ nexus. Hence, H4 was also supported.

\section{Additional analysis}

This section attempts to deal with the problem of endogeneity, which has arguably been identified in the extant literature as the single most common issue in CG research. As such, ignorance of endogeneity issues may result in unreliable causality inferences (Roberts \& Whited 2013; Tshipa et al. 2018). Arguably, variables are typically endogenous, instruments are scarce and causality relationships are complicated; nevertheless, it has equally been argued that most econometric methods utilised in extant literature are effective remedies to mitigate endogeneity issues (Li 2016). 
TABLE 4: Seemingly unrelated regression results examining the moderating role of board independence and managerial ownership on voluntary social performance disclosure and firm profitability nexus.

\begin{tabular}{|c|c|c|c|c|c|c|c|c|c|c|}
\hline \multirow[t]{3}{*}{ Variable } & \multicolumn{4}{|c|}{ Model 1} & \multirow{2}{*}{\multicolumn{2}{|c|}{$\begin{array}{c}\text { Model } 2 \\
\text { TQ }\end{array}$}} & \multirow{2}{*}{\multicolumn{2}{|c|}{$\begin{array}{c}\text { Model } 3 \\
\text { TQ }\end{array}$}} & \multirow{2}{*}{\multicolumn{2}{|c|}{$\begin{array}{c}\text { Model } 4 \\
\text { TQ }\end{array}$}} \\
\hline & \multicolumn{2}{|c|}{ TQ } & \multicolumn{2}{|c|}{ SPD } & & & & & & \\
\hline & $\beta$ & z-stats & $\beta$ & z-stats & $\beta$ & z-stats & $\beta$ & z-stats & $\beta$ & z-stats \\
\hline Constant & $7.296 * * *$ & 7.39 & $6.264 * * *$ & -5.42 & $7.168 * * *$ & 6.01 & $7.067 * * *$ & 6.02 & $6.750 * * *$ & 5.75 \\
\hline \multicolumn{11}{|l|}{ Control variables } \\
\hline FSIZE & $-0.332 * * *$ & -8.48 & 0.030 & 1.32 & $-0.351 * * *$ & -8.07 & $-0.356 * * *$ & -8.26 & $-0.353 * * *$ & -8.25 \\
\hline FAGE & -0.035 & -0.34 & 0.021 & 0.34 & -0.031 & -0.26 & -0.066 & -0.55 & -0.093 & -0.77 \\
\hline CEO_CHAIR & $1.539 * * *$ & 3.34 & 0.128 & 0.49 & $1.619 * * *$ & 3.19 & $1.690 * * *$ & 3.39 & $1.676 * * *$ & 3.37 \\
\hline ROA & $1.432^{* *}$ & 1.97 & $0.921 * * *$ & 3.40 & $1.524 *$ & 1.86 & $1.551^{*}$ & 1.93 & $1.647 * *$ & 2.05 \\
\hline CRSCOM & -0.229 & -0.49 & 0.106 & 0.25 & -0.226 & -0.43 & -0.147 & -0.28 & -0.125 & -0.24 \\
\hline LEV & -0.011 & -0.26 & -0.028 & -1.20 & -0.005 & -0.11 & -0.006 & -0.14 & -0.010 & -0.22 \\
\hline \multicolumn{11}{|c|}{ Independent variable } \\
\hline SPD & - & - & - & - & 0.078 & 1.01 & 0.105 & 1.07 & $0.150 *$ & 1.88 \\
\hline \multicolumn{11}{|l|}{$\begin{array}{l}\text { Moderating } \\
\text { variables }\end{array}$} \\
\hline SPD* NEDs & - & - & - & - & - & - & 0.108 & 1.39 & $0.228^{* *}$ & 2.00 \\
\hline SPD*MO & - & - & - & - & - & - & $0.393 * * *$ & 3.56 & $0.662 * * *$ & 3.90 \\
\hline SPD* NEDs *MO & - & - & - & - & - & - & - & - & $0.398 * *$ & 2.12 \\
\hline Industry effects $\dagger$ & - & - & - & - & - & - & - & - & - & - \\
\hline Years-effects $\dagger$ & - & - & - & - & - & - & - & - & - & - \\
\hline Wald's chi-squared & $149.22 * * * *$ & 18 & $658.07 * * * *$ & 18 & $127.15 * * * *$ & - & $143.25 * * * *$ & - & $148.78 * * * *$ & - \\
\hline RMSE & 2.440 & - & 1.2877 & - & 2.4976 & - & 2.451 & - & 2.443 & - \\
\hline$R^{2}$ & 0.1669 & - & 0.5145 & - & 0.1699 & - & 0.1877 & - & 0.1935 & - \\
\hline$\Delta R^{2}$ & - & - & - & - & 0.0030 & - & 0.0178 & - & 0.0058 & - \\
\hline Observations & 745 & - & 745 & - & 621 & - & 620 & - & 620 & - \\
\hline
\end{tabular}

Therefore, we examine the robustness of our main findings in Table 3 compared to another modelling technique. Hence, we employ the seemingly unrelated regression (SURE) model, with a 1-year lagged independent variable. Thus, we introduced a 1-year lag between SPD and TQ, such that profitability in a given year (i.e. $\mathrm{TQ}_{t}$ ) depends on the previous year's voluntary SPD (i.e. $\mathrm{SPD}_{t-1}$ ) (Sampong et al. 2018). Seemingly unrelated regression produces efficient estimates in cases of non-identical prediction equations. This is achieved by weighting the estimates by the covariance of the residuals from the individual regressions (Greene 2008; Kennedy 1998).

In Table 4, and consistent with the procedure followed in the main findings, three models were estimated to test the stated hypotheses using the SURE (with a 1-year lag of SPD) to test the robustness of our earlier findings, utilising the econometric model below:

$$
\begin{aligned}
T Q_{i t}= & b_{0}+b_{1} S P D I_{i t-1}+b_{2} S P D I_{i t-1} * N E D s_{i t}+b_{3} S P D I_{i t-1} * M O_{i t-1} \\
& +b_{4} S P D I_{i t} * N E D s_{i t} * M O_{i t}+\sum_{i=1}^{7} b_{5} \text { CONTROLS }_{i t}+\varepsilon_{i t}
\end{aligned}
$$

[Eqn 3]

In Equation 3, $b_{0-5}$ are the intercepts, $\varepsilon$ is the error term, $S P D I_{i t-1}$ is the 1-year lag of a main independent variable and CONTROLS are the control variables. All variables are as defined in Table 1.
The baseline Table 4, Model 1 tests the effect of all control variables on TQ and SPD producing $\mathrm{R}^{2}$ values of 0.167 and 0.515 . Table 4, Models 2-4 indicate a better model fit; particularly all chi-squared values are statistically significant at 0.0001 . Table 4, Model 2 shows a positive $(\beta=0.078)$ direct voluntary SPD and FP association in the long term, with $R^{2}$ and $\Delta R^{2}$ values of 0.170 and 0.003 . Thus, again H1 is supported. Table 4, Model 3 reveals $R^{2}$ and $\Delta R^{2}$ values of 0.187 and 0.018 . Again, it shows that NEDs (BIND) positively $(\beta=0.108)$ moderates the direct positive voluntary SPD and FP nexus, when compared with the outcome in Table 4, Model 3 ( $\beta=0.078$ ). Again, the effect is nonsignificant. Table 4 , Model 3 again shows a significantly positive ( $\beta=0.393 ; p \leq 0.01)$ moderating effect of $\mathrm{MO}$ on the direct positive voluntary SPD and FP nexus. Hence, $\mathrm{H} 2$ and $\mathrm{H} 3$ are all supported. Lastly, Table 4 , Model 4 (with $\mathrm{R}^{2}$ and $\Delta \mathrm{R}^{2}$ values of 0.194 and 0.006 ) shows that the interactive effect of NEDs and MO significantly positively ( $\beta=0.398 ; p \leq 0.05$ ) moderates the direct voluntary SPD and FP nexus in the long term. The results in Table 3 and Table 4 show that the study's findings are robust, with only changes in the coefficients in Table 4 due to the 1-year lag of the independent variable. Hence, the results are qualitatively robust.

\section{Discussion}

This study examines the complementary role of NEDs (BIND) and MO on the voluntary SPD and long-term FP nexus. Although there is growing research examining the bundle usage of CG mechanisms on organisational 
outcomes, most prior studies have focused on developed countries, with relatively limited research in less-developed economies. Therefore, this study attempts to bridge this gap in extant literature. Based on 126 manually extracted unbalanced data of listed companies on the JSE and utilising the 45 provisions of the GRI-G3.1 guidelines on social performance indicators, as a measure of voluntary SPD, this study finds support for all four stated hypotheses, based on the GLS and SURE (with 1-year lag of the main independent variable). Firstly, this study found a positive voluntary SPD and long-term profitability association for H1. Secondly, the proportion of NEDs positively moderates voluntary SPD and long-term profitability association for $\mathrm{H} 2$. Thirdly, the percentage of managerial share-ownership and significantly positively moderates voluntary SPD and long-term profitability association for H3. Lastly, we document a significantly positive moderating effect of the complementary effect of NEDs (BIND) and MO on the association between voluntary SPD and long-term profitability. The finding of $\mathrm{H} 4$ suggests that the multiplicative effects at the board management level are significant to mitigate agency problems in the long term. This particular outcome is consistent with previous studies that examined the complementary role of CG mechanisms on organisational outcomes, like CSR. For instance, Galbreath (2016) shows that a senior CSR manager appears to complement the board, positively moderating the impact of board resources on CSR. Similarly, Misangyi and Acharya (2014) found that high profits result when CEO incentive alignment and monitoring mechanisms work together as complements. Hence, this study provides support for ongoing debates within the extant literature promoting the complementary or substitutive effects of CG mechanisms, in an African context. Importantly, it provides new additional evidence which is very important to present a much more complete understanding and picture of the ongoing debate within the extant literature, in different institutional contexts.

\section{Conclusion}

Practically, the study's findings should be of interest to the SA corporate market, and the sub-Saharan African region. For instance, although SA CG regimes promote BIND, it is suggested that their application should be done with caution, bearing in mind the associated costs and benefits, at different stages of the business life cycle. Thus, we predict that at any organisational stage (i.e. short, medium and long terms), performance should be a reflection of the available monitoring roles and incentive provisions. For instance, as advocated by the King III code, section 2:18:4 (IoDSA, 2009), boards should consider whether their levels of diversity make them effective; they should be tied to the proportion of board management monitoring roles and incentive levels at each stage. Theoretically, we contribute by exploring a multi-theoretical view within the CG and CSR literature, recognising that there may be limitations with respect to using a single theory to explore the unique role of CG mechanisms on voluntary social disclosure and profitability, given the multiplicity within corporate motivations.
Although this study extends our understanding on bundle usage of CG mechanisms on voluntary SPD, future research avenues have been identified for further investigation. Firstly, this study examines the complementary role of CG mechanisms on voluntary SPD and long-term profitability. Future studies could re-examine the complementary or substitutive roles of CG mechanisms on different CSR measures, like environmental disclosures. In addition, this study in the sub-Saharan African context is only limited to SA. Future research could utilise a cross-country data set to add to our understanding in different institutional contexts. Lastly, future research could look at other board diversity measures, like the complementary or substitutive role of women and ethnic minorities. Overall, this study presents corporate regulators, boards and management, and policymakers with additional insight into pursuing an 'appropriate mix' using CG mechanisms at different stages of the organisation.

\section{Acknowledgements}

The authors would like to thank the anonymous reviewers for their time and suggestions which were most helpful in refining and improving this article. The authors gratefully acknowledge the financial support of the Ministry of Education of Humanities and Social Science Grant of China (grant number: 17YJC790127).

\section{Competing interests}

The authors have declared that no competing interest exists.

\section{Authors' contributions}

F.S. was responsible for conceptualisation of the study, data collection, cleaning, literature review, research design and methodology, analysis and interpretation of results, and drafting and reviews of the manuscript. S.N. was responsible for supervision and guidance on all aspects of this article. G.K.A. and K.O.B. were involved in data collection, cleaning, coding, literature review, methodology, analyses and interpretation of results, and reviews of the manuscript. All the authors read and approved the manuscript before its submission.

\section{Ethical consideration}

This article followed all ethical standards for carrying out research.

\section{Funding information}

This research was funded by the Ministry of Education of Humanities and Social Science Grant of China (grant number: 17YJC790127).

\section{Data availability statement}

The authors confirm that the data supporting the findings of this study are available within the article. 


\section{Disclaimer}

The views and opinions expressed in this article are those of the authors and do not necessarily reflect the official policy or position of any affiliated agency of the authors.

\section{References}

Adams, C.A., 2004, 'The ethical, social and environmental reporting- performance portrayal gap', Accounting, Auditing \& Accountability Journal 17(5), 731-757. https://doi.org/10.1108/09513570410567791

Aguilera, R.V., Filatotchev, I., Gospel, H. \& Jackson, G., 2008, 'An organizational approach to comparative corporate governance: Costs, contingencies, and complementarities', Organization Science 19(3), 475-492. https://doi. org/10.1287/orsc.1070.0322

Arora, P. \& Dharwadkar, R., 2011, 'Corporate governance and corporate social responsibility (CSR): The moderating roles of attainment discrepancy ... corporate governance and corporate social responsibility (CSR): The moderating roles of attainment and corporate social responsibility (CSR): The moderating roles of attainment
discrepancy and organization slack', Corporate Governance An International Review discrepancy and organization slack', Corporate Governance An Intern
19(2), 136-152. https://doi.org/10.1111/j.1467-8683.2010.00843.x

Baird, P.L., Geylani, P.C. \& Roberts, J.A., 2012, 'Corporate social and financial performance re-examined: Industry effects in a linear mixed model analysis', Journal of Business Ethics 109(3), 367-388. https://doi.org/10.1007/s10551-0111135-z

Barr, G., Gerson, J. \& Kanto, B., 1995, 'Shareholders as agents and principals: The case for South Africa's corporate governance system', Journal of Applied Corporate Finance 8(1), 18-31. https://doi.org/10.1111/j.1745-6622.1995.tb00268.x

Block, S.B. \& Hirt, G.A., 2002, Foundations of financial management, 10th edn., McGraw-Hill, Boston, MA

Campbell, J.L., 2007, 'Why would corporations behave in socially responsible ways? An institutional theory of corporate social responsibility', Academy of Management institutional theory of corporate social responsibility', Academ
Review 32(3), 946-967. https://doi.org/10.2307/20159343

Dawson, J.F., 2014, 'Moderation in management research: What, why, when, and how', Journal of Business and Psychology 29(1), 1-19. https://doi.org/10.1007/ s10869-013-9308-7

De Klerk, M. \& De Villiers, C., 2012, 'The value relevance of corporate responsibility reporting: South African evidence, Meditari Accountancy Research 20(1), 21-38. https://doi.org/10.1108/10222521211234200

Dierickx, I. \& Cool, K., 1989, 'Asset stock accumulation and the sustainability of competitive advantage', Management Science 35(12), 1504-1511. https://doi. org/10.1287/mnsc.35.12.1504

Donaldson, T. \& Preston, L.E., 1995, 'The stakeholder theory of the corporation: Concepts, evidence, and implications', Academy of Management Review 20(1) 65-91, viewed from http://www.jstor.org/stable/258887

Du Toit, E. \& Lekoloane, K., 2018, 'Corporate social responsibility and financial performance: Evidence from the Johannesburg Stock Exchange, South Africa', performance: Evidence from the Johannesburg Stock Exchange, South Africa',
South African Journal of Economic and Management Sciences 21(1), a1799. South African Journal of Economic and
https://doi.org/10.4102/sajems.v21i1.1799

Fama, E. \& Jensen, M., 1983, 'The separation of ownership and control', Journal of Law and Economics 26(2), 301-325. https://doi.org/10.1086/467037

Foss, N.J., 1998, 'The resource-based perspective: An assessment and diagnosis of problems', Scandinavian Journal of Management 14(3), 133-149. https://doi. org/10.1016/S0956-5221(97)00030-4

Galbreath, J., 2016, 'When do board and management resources complement each other? A study of effects on corporate social responsibility', Journal of Business Ethics 136(2), 281-292. https://doi.org/10.1007/s10551-014-2519-7

Garcia-Sanchez, I.M., Cuadrado-Ballesteros, B. \& Frias-Aceituno, J.V., 2016, 'Impact of the institutional macro context on the voluntary disclosure of CSR information, Long Range Planning 49(1), 15-35. https://doi.org/10.1016/j.Irp.2015.02.004

Graves, S. \& Waddock, S., 1994, 'Institutional owners and corporate social performance', Academy of Management Journal 37(4), 1034-1046. https://doi. org $/ 10.5465 / 256611$

Greene, W.H., 2008, Econometric analysis, 6th edn., Prentice-Hall, Upper Saddle River, NJ.

Guthrie, J., Petty, R., Yongvanich, K. \& Ricceri, F., 2004, 'Using content analysis as a research method to inquire into intellectual capital reporting', Journal of Intellectual Capital 5(2), 282-293. https://doi.org/10.1108/14691930410533704

Gyapong, E. \& Afrifa, G.A., 2019, 'The simultaneous disclosure of shareholder and stakeholder corporate governance practices and their antecedents', International Journal of Finance and Economics 24(1), 260-287. https://doi.org/10.1002/ ijfe.1661

Haniffa, R.M. \& Cooke, T.E., 2002, 'Culture, corporate governance and disclosure in Malaysian corporations', Abacus: A Journal of Accounting, Finance \& Business Studies 38(3), 317-349. https://doi.org/10.1111/1467-6281.00112

Haniffa, R.M. \& Hudaib, M., 2006, 'Corporate governance structure and performance of Malaysian listed companies', Journal of Business Finance \& Accounting 33(7 \& 8), 1034-1062. https://doi.org/10.1111/j.1468-5957.2006.00594.x

Haynes, K.T. \& Hillman, A., 2010, 'The effect of board capital and CEO power on strategic change', Strategic Management Journal 31(11), 1145-1163. https://doi. org/10.1002/smj.859

Hillman, A. J., \& Dalziel, T., 2003, Boards of directors and firm performance: Integrating agency and resource dependence perspectives. Academy of Management Review, 28(3), 383-396. https://doi.org/10.5465/AMR.2003.10196729
Hoje, J. \& Harjoto, M.A., 2011, 'Corporate governance and firm value: The impact of corporate social responsibility', Journal of Business Ethics 103(3), 351-383. of corporate social responsibility', Journal
$\mathrm{https}: / /$ doi.org/10.1007/s10551-011-0869-y

Horn, R., De Klerk, M. \& De Villiers, C., 2018, 'The association between corporate social responsibility reporting and firm value for South African firms', South Africa Journal of Economics and Management Sciences 21(1), a1964. https://doi. org/10.4102/sajems.v21i1.1964

IoDSA, 2009, King report on corporate governance for South Africa (King III), Institute of Directors, Johannesburg.

Jensen, M.C. \& Meckling, W.H., 1976, 'Theory of the firm: Managerial behavior agency costs and ownership structure', Journal of Financial Economics 3(4), 305-360. https://doi.org/10.1016/0304-405X(76)90026-X

Johnson, R.A. \& Greening, D.W., 1999, 'The effects of corporate governance and institutional ownership types on corporate social performance' Academy of Management 42(5), 564-576.

Kennedy, P.E., 1998, A guide to econometrics, 4th edn., MIT Press, Cambridge, MA.

Krippendorff, K., 2004, Content analysis: An introduction to its methodology, Sage Publications, London.

LaPorta, R., Lopez-de Silanes, F., Shleifer, A. \& Vishny, R., 2000, 'Investor protection and corporate governance', Journal of Financial Economics 48(1-2), 3-27. https:// doi.org/10.1016/S0304-405X(00)00065-9

Li, F., 2016, 'Endogeneity in CEO power: A survey and experiment', Investment Analysts Journal 45(3), 149-162. https://doi.org/10.1080/10293523.2016.1151985

Mahapatra, S., 1984, 'Investor reaction to a corporate social accounting', Journal of Business Finance \& Accounting 11(1), 29-40. https://doi.org/10.1111/j.1468-5957.1984. tb00054.x

Mahoney, L.S., Thorne, L., Cecil, L. \& LaGore, W., 2013, 'A research note on standalone corporate social responsibility reports: Signaling or greenwashing?', Critical Perspectives on Accounting 24(4-5), 350-359. https://doi.org/10.1016/j.cpa.2012.09.008

Mangel, R. \& Singh, H., 1993, 'Ownership structure, board relationships and CEO compensation in large US corporations', Accounting and Business Research 23(91), 339-350. https://doi.org/10.1080/00014788.1993.9729902

Margolis, J.D. \& Walsh, J.P., 2003, 'Misery loves companies: Rethinking social initiatives by business', Administrative Science Quarterly 48(2), 268-305, viewed 30 June 2020, from https://www.jstor.org/stable/3556659.

McConnell, J.J. \& Servaes, H., 1990, 'Additional evidence on equity ownership and corporate value', Journal of Financial Economics 27(2), 595-612. https://doi. org/10.1016/0304-405X(90)90069-C

McGuire, J.B., Dow, S. \& Argheyd, K., 2003, 'CEO incentives and corporate social performance', Journal of Business Ethics 45(4), 341-359. https://doi. org/10.1023/A:1024119604363

McGuire, J.B., Sundgren, A. \& Schneeweis, T., 1988, 'Corporate social responsibility and firm financial performance', Academy of Management Journal 31(4), 854-972. https://doi.org/10.5465/256342

McWilliams, A. \& Siegel, D., 2000, 'Corporate social responsibility and financial performance: Correlation or misspecification?', Strategic Management Journa/21(5), 603-609. https://doi.org/10.1002/(SICI)1097-0266(200005)21:5\%3C603::AID603-609. https://doi.org
SMJ101\%3E3.0.CO;2-3

Milgrom, P., \& Roberts, J. 1992, 'Economics, organizations, and management'. Englewood Cliffs, NJ: Pren- tice Hall.

Misangyi, V.F. \& Acharya, A.G., 2014, 'Substitutes or complements? A configurational examination of corporate governance mechanisms', Academy of Management Journal 57(6), 1681-1705. https://doi.org/10.5465/amj.2012.0728

Ntim, C.G. \& Soobaroyen, T., 2013, 'Corporate governance and performance in socially responsible corporations: New empirical insights from a neo-institutional framework', Corporate Governance An International Review 21(5), 468-494. https://doi.org/10.1111/corg.12026

Oh, W.Y., Chang, Y.K. \& Cheng, Z., 2016, 'When CEO career horizon problems matter for corporate social responsibility: The moderating roles of industry-level discretion and blockholder ownership', Journal of Business Ethics 133(2), 279-291. https:// doi.org/10.1007/s10551-014-2397-z

Oh, W.-Y., Chang, Y.K. \& Kim, T.-Y., 2018, 'Complementary or substitutive effects? Corporate governance mechanisms and corporate social responsibility', Journal of Management 44(7), 2716-2739. https://doi.org/10.1177/0149206316653804

Orlitzky, M., Schmidt, F.L. \& Rynes, S.L., 2003, 'Corporate social and financial performance: A meta-analysis', Organization Studies 24(3), 403-441. https://doi. org/10.1177/0170840603024003910

Peng, C. \& Yang, M., 2014, 'The effect of corporate social performance on financial performance: The moderating effect of ownership concentration', Journal of Business Ethics 123(1), 171-182. https://doi.org/10.1007/s10551-013-1809-9

Pfeffer, J., 1973, 'Size, composition, and function of hospital boards of directors: A study of organization-environmental linkage', Administrative Science Quarterly 18, 349-364.

Pfeffer, J. \& Salancik, G.R., 1978, The external control of organizations: A resource dependence perspective, Harper \& Row, New York, NY.

Pfeffer, J. \& Salancik, G.R., 2003, The external control of organizations: A resource dependence perspective, Stanford University Press, Stanford, CA

Podsakoff, P.M., MacKenzie, S.B., Jeong-Yeon, L. \& Podsakoff, N.P., 2003, 'Common method biases in behavioral research: A critical review of the literature and recommended remedies', Journal of Applied Psychology 88(5), 879-903. https:// doi.org/10.1037/0021-9010.88.5.879

Potter, W.J. \& Levine-Donnerstein, D., 1999, 'Rethinking validity and reliability in content analysis', Journal of Applied Communication Research 27(3), 258-284. https://doi.org/10.1080/00909889909365539 
Preston, L.E. \& O'Bannon, D.P., 1997, 'The corporate social-financial performance relationship: A typology and analysis', Business and Society 36(4), 419-429. relationship: A typology and analysis', Business
https://doi.org/10.1177\%2F000765039703600406

Reverte, C., 2009, 'Determinants of corporate social responsibility disclosure ratings by Spanish listed firms', Journal of Business Ethics 88(2), 351-366. https://doi. org/10.1007/s10551-008-9968-9

Roberts, M.R. \& Whited, T.M., 2013, 'Endogeneity in empirical corporate finance', in M.H. Goerge, M. Constantinides \& M.S. Rene (eds.), Handbook of the economics of finance, vol. 2, Par, pp. 493-572, Elsevier, Saint Louis, MO.

Sampong, F., Boahene, K.O. \& Kweitsu, G., 2018, 'Apartheid-induced corporate social responsibility in the context of South Africa: A review', Journal of Developing Country Studies 8(10), 62-71, viewed 01 July 2020, from https://iiste.org/ Journals/index.php/DCS/article/view/44879/46298.

Sampong, F., Song, N., Boahene, K.O. \& Wadei, K.A., 2018, 'Disclosure of CSR performance and firm value: New evidence from South Africa on the basis of the GRI guidelines for sustainability disclosure', Sustainability (Switzerland) 10(12) 4518. https://doi.org/10.3390/su10124518

Schroeder, M.A., 1990, 'Diagnosing and dealing with multicollinearity', Western Journal of Nursing Research 12(2), 175-187. https://doi.org/10.1177/019394599001200204

Southall, R., 2004, 'BEE 10 years on', Enterprise, 104-108.
Spicer, B.H., 1978, 'Investors, corporate social performance and information disclosure: An empirical study', The Accounting Review 53(1), 94-111.

Stanwick, P.A. \& Stanwick, S.D., 1998, 'The relationship between corporate social performance, and organizational size, financial performance, and environmental performance: An empirical examination', Journal of Business Ethics 17(2), 195-204. https://doi.org/10.1023/A:1005784421547

Sundaramurthy, C. \& Lewis, M., 2003, 'Control and collaboration: Paradoxes of governance', Academy of Management Review 28(3), 397-415. https://doi. org/10.5465/amr.2003.10196737

Tshipa, J., Brummer, L.M., Wolmarans, H. \& Du Toit, E., 2018, 'The effect of industry nuances on the relationship between corporate governance and financia performance: Evidence from South African listed companies', South Africa Journal of Economics and Management Sciences 21(1), a1964. https://doi.org/10.4102/ sajems.v21i1.1964

Waddock, S. \& Graves, S.B., 1997, 'The corporate social performance-financial performance link', Strategic Management Journal 18(4), 303-319. https:// doi.org/10.1002/(SICI)1097-0266(199704)18:4\%3C303::AID-SMJ869\%3E3. $0 . \mathrm{CO} ; 2-\mathrm{G}$

Wernerfelt, B., 1984, 'A resource-based view of the firm', Strategic Management Journal 5(2), 171-180. https://doi.org/10.1002/smj.4250050207 